\title{
SEBUAH STUDI TENTANG DIALOG INTERRELIGIUS
}

\author{
Armada Riyanto*
}

\begin{abstract}
The truth is that interreligious contacts, together with ecumenical dialogue, now seem to be obligatory paths, in order to ensure that the many painful wounds inflicted over the course of centuries will not be repeated, and indeed that any such wounds still remaining will soon be healed" (John Paul II, Rome, N ovember 13, 1992). By “obligatory path" thelate John Paul II means that interreligious dialogue is one of the urgent ways for Christians as well as people of other faiths to cultivate a theological sense of togetherness. I have recently published such a topic in Dialog Interreligius: H istorisitas, Tesis, Pergumulan, Wajah (Yogyakarta: Kanisius, 2010). Thebook depictsa lengthly attempt to study interreligious dialogue from several perspectives. I would call such perspectives "history, thesis, discourse, and face." This article is a sort of executive summary of the research that indicates the methodology and face of the pastoral activities of a particular Church, Indonesia. Study of interreligious dialogue should include or even start from the existential experience of the very protagonists, i. e. local Churches that live their daily life with people of other faiths.
\end{abstract}

Keywords: Dialog interreligius (Inter-religous dialogue), perspektif (persepctive), Konsili Vatikan II (Second V atican Council), historisitas (historicity), tesis (thesis), wajah dialogal (dialogical picture), pastoral (pastoral).

* A rmada Riyanto, Sekolah Tinggi Filsafat dan Teologi, Widya Sasana, JI. Terusan Rajabasa 2, M alang. Telpon: (0341) 552120. Fax: (0341) 566676. E-mail: stftws@gmail.com. E-mail (pribadi): fxarmadacm@gmail.com. 


\section{PENDAHULUAN}

Penulis ingin menyebut ranah dialog dengan terminologi "dialogalitas." Dialogalitas menyentuh natura (kodrat) kehadiran manusia bersama yang lain. Tatkala Gereja Vatikan II mendeklarasikan diri sebagai Gereja solider, bahwa "kegembiraan dan harapan, duka, dan kecemasan putraputri dunia adalah kegembiraan dan harapan, duka, dan kecemasan putra-putri Gereja" (Gaudium et Spes, 1), esensi halnya menjadi mungkin dalam dialogalitas. N ostra A etate menjadi salah satu emblem dialogalitas yang menyentuh ranah agama (umat beriman) lain. Kita menyebutnya "dialog interreligius." Setiap upaya pembakuan studi teologis-filosofis dialog interreligius hampir pasti merupakan sebuah pencarian terusmenerus. Karakter dialogalitas mengatakan dinamisme yang tidak mungkin mandeg pada suatu eksposisi teologis-filosofis paling canggih sekali pun.

Penel itian tentang tema ini dengan beberapa perspektif penulis jalankan sejak 1990-an dan berlangsung selama hampir dua puluh tahun terakhir, serta menghasilkan sebuah buku yang telah diterbitkan. ${ }^{1}$ Secara historis dekadesembilan puluhan merupakan periodedialogal dalam peradaban manusia, menyusul ambruknya ideologi komunis yang menjadi antitesis kebebasan rasionalitas. Dalam kawalan mendiang Paus Yohanes Paulus II, dokumen-dokumen Konsili Vatikan II mendapatkan penerjemahannya secara luas dalam ranah tata politik dunia, upaya-upaya ekumenis, serta dialog interreligius.

\section{DIALOGALITAS DAN PERSPEKTIF STUDI}

Studi tentang dial og interreligius mengenal diversitas perspektif metodologi. Dengan perspektif tidak hanya dimaksudkan fokus sudut pandang melainkan juga keterbatasan. Keterbatasan dalam ranah keilmuan justru menampilkan "kekayaan," semata-mata karena ruang investigasi dibuka lebar bagi studi-studi selanjutnya. Buku D ialog Interreligius² mengemuka-

1 A rmada Riyanto, D ialog Interreligius: H istorisitas, Tesis, Pergumulan, W ajah (Yogyakarta: Kanisius, 2010).

2 Selanjutnya disingkat DI. 
kan diversitas perspektif, yaitu historisitas, tesis, pergumulan, dan wajah.

Disebuthistorisitas, sebab dialog memiliki sejarah. Dialog interreligius tidak terjadi secara mendadak atau sekali jadi. Dialog memiliki dinamika perkembangannya. Tetapi bukan perkembangan kronologis dari aneka aktivitas dialogal, melainkan lebih mengemukakan perkembangan doktrinal teologis dan aksentuasi makna aktualitasnya dalam periode satu ke periode lainnya. Jika kita katakan bahwa pelaku dialog pertama-tama adalah komunitas Gereja lokal, kekayaan diversitas perspektif historis dialog interreligius sungguh luar biasa.

Dengan tesis hendak diajukan dalam DI penelitian atas pandangan dokumen-dokumen otoritatif dari Gereja Katolik. Dengan menyimak tesis-tesis dialogal dokumen-dokumen Konsili Vatikan II dan Pascakonsili Vatikan II yang maha penting itu, orang dapat menelusuri dan mempelajari perkembangan sistematis doktrinal nya. Ketika tesis-tesis dari aneka dokumen digali, sangat mungkin gagasan-gagasan indah yang' dikemukakan tidak tersusun sistematis. Karena itu, dalam DI setelah tesis disajikan diberikan sistematisasi ajarannya.

Perspektif pergumulan mengatakan kebenaran bahwa tesis-tesis doktrinal tentang dialog interreligius dalam dokumen-dokumen memasuki fase baru, tahapan praksis dan pengalaman. Dengan "pergumulan" juga dimaksudkan bahwa pembahasan bagian ini tidak otoritatif melainkan "eksistensial" sepanjang menjadi milik teolog ${ }^{3}$ dan merupakan sebuah "peziarahan" sejauh menjadi praksis atau pengalaman Gereja lokal. Mendiang Paus Yohanes Paulus II menjadi salah satu contoh terdepan men of dialogue yang mengukir peziarahan unik dalam mempromosikan perspektif dialogal hidup Gereja Katolik. Yohanes Paulus II-lah yang secara mencolok menghadirkan Gereja dengan karakter dialogal.

Wajah mengatakan kehadiran, kesaksian, pengalaman. Dua bagian akhir dari buku DI menyajikan perspektif wajah dalam kehadiran dan

3 Di antaranya yang menonjol: Karl Rahner dengan konsep "Kristen Anonim;" Hans Küng dengan "teologi ekumenis;" Stanley J. Samartha dengan "R elational D istinctiveness Kristus," dan Paul Tillich dengan "ubiquitas Roh Allah." 
kesaksian Gereja Katolik Asia dan Indonesia. Pembahasan tentang wajah juga hendak berkata bahwa pembahasan dialog interreligius tidak pernah tuntas dan habis seiring dinamika pengalaman dan kesaksian yang tak pernah tuntas dari Gereja-gereja lokal dalam menyusuri loronglorong aneka tantangan dialog interreligius. Wajah adalah kehadiran eksistensial. Dengan wajah dimaksudkan realitas sebagaimana yang tampak, terjadi, dan menjadi pengalaman sehari-hari. Terminologi "wajah" diatribusikan di sini untuk memberi artikulasi karakter dinamisnya. Wajah tidak pernah statis. Dalam wajah, dihadirkan pengalaman perjuangan dan jatuh bangun untuk menerjemahkan pesanpesan fundamental. Wajah juga merupakan aktualitas pengalaman. Bagaimana kehadiran wajah dialogal Gereja Katolik Asia? Inilah pertanyaan utama yang hendak diurai. Pembahasannya terdiri dari dua bagian: (a) tentang peziarahan Gereja Katolik Asia dalam institusinya yang disebut Federations of A sian Bishops' Conferences (FABC), dan (b) tentang paradigma simakan Gereja Asia untuk menerjemahkan pandangan Konsili Vatikan II dan Pascakonsili Vatikan II dalam peziarahannya dengan wajah dialogal (disimak dari beberapa dokumennya).

Dalam konteks "wajah Indonesia" dialog interreligius tidak dapat dipisahkan dari konteks kebijakan sosio-politik yang merupakan ranah relasi sehari-hari antarumat pemeluk agama, sebab dialog interreligius tidak dapat dimaknai sekedar sebagai sebuah perjumpaan formal antarpemimpin atau antarumat beragama (sebagaimana biasanya dikerjakan) dalam aneka seminar atau silaturahmi. Dialog interreligius membutuhkan suasana kebebasan dan saling menghormati keanekaragaman. Dialog interreligius juga mengatasi sekat-sekat formal ketentuan hukum dan undang-undang yang kerap kali justru membatasi dan merepresi eksistensi dan dinamisme agama. Dialog interreligius juga mencegah aneka macam cetusan perilaku dan kebijakan undang-undang yang diskriminatif. Karena ciri kemajemukan masyarakatnya sudah sedemikian jelas, tidak disangsikan lagi bahwa dialog interreligius sangat relevan bagi Gereja Indonesia. Model persekutuan yang dialogal bahkan tidak lagi merupakan alternatif, melainkan tuntutan mutlak bagi Gereja 
Indonesia yang dalam pengalaman eksistensialnya menghayati diri sebagai kawanan kecil dalam bangsa yang bhineka tunggal ika, biarpun untuk mereal isasikan tuntutan itu, ia harus mel ewati lorong-lorong gelap, penuh tantangan dan ancaman, dan tidak jarang disertai dengan salib berat.

Dengan demikian, karakter pembahasan penelitian buku DI menggabungkan beberapa perspektif historis-otoritatif-diskursif-praksis. Dialog interreligius memiliki dinamika historis yang mengal ir dari tesis-tesis ajaran pembaruan Konsili Vatikan II, bermuara pada lautan pergumulan hidup Gereja setempat, dan dimurnikan dalam aneka pengalaman jatuh bangun saat menyusuri jalan-jalan terjal keseharian menghadirkan kasih, perdamaian, dan keadilan.

\section{DIALOGALITAS DAN KONSILI VATIKAN II}

Gereja abdi atau pelayan; Gereja orang miskin; Gereja yang solider dan membela para tertindas; Gereja yang berdialog dan bekerjasama dengan umat beragama lain; itulah temuan-temuan identitas jati diri kehadiran Gereja Katolik Asia dan Indonesia. Temuan ini berasal dari angin segar kesadaran baru Konsili Vatikan II yang berhembus kencang di Asia. Gereja Asia di tengah-tengah kemajemukan, memahami diri sebagai Gereja abdi. ${ }^{4}$ Gereja Katolik mengabdi semua orang dari segala macam latar belakang budaya, tradisi religius, agama, dan sosial ekonomi. Gereja memandang umat beragama lain bukan sebagai orang lain melainkan partner melayani, partner mengabdi.

Untuk mengabdi, Gereja berusaha lebih mengakar dalam tradisi budaya setempat, dan untuk mengakar, Gereja melakukan aktivitas permanen, dialog; sebab Gereja abdi pada prinsipnya adalah Gereja yang berdialog. Gereja partikular adalah Gereja yang mendapat wujudnya dari suatu bangsa yang sungguh berakar dalam kebudayaannya sendiri. Secara konkret hal ini berarti bahwa Gereja mesti terus-menerus dengan

4 Lihat hasil sidang paripurna Federation of A sian Bishops' Conferences (FABC) yang ketiga pada 1982, di Bangkok, Thailand. 
cinta dan rendah hati berdialog dengan tradisi-tradisi kebudayaan, religiositas maupun agama-agama setempat. ${ }^{5}$

Dengan ini hendak dikatakan suatu gagasan bahwa membangun dialog berarti membangun Gereja setempat. Menjalin hubungan yang akrab dengan aneka tradisi budaya dan agama di mana Gereja hadir berarti merajut benang-benang penghayatan iman yang makin mengakar dalam masyarakat setempat. Atau, seakan makin tegas disadari bahwa Gereja partikular justru akan menemukan kesempurnaannya bila berdialog dengan seluruh bangsa manusia yang menjadi tetangga dan sahabat dalam hidup sehari-hari.

Dari pengalaman hidup kita, muncul keyakinan bahwa dialog telah menjadi kunci yang selama ini kita cari. Tetapi dialog di sini bukan dalam arti sebagaimana sering kali kita pahami, melainkan sebagai kesaksian akan Kristus dalam perbuatan dan kata-kata dengan terlibat di dalam masyarakat, dalam hidup sehari-hari, dalam konteks budaya, tradisi religius, dan kondisi-kondisi sosio-ekonomis. ${ }^{6}$ Dewasa ini teologi dialog terasa kuat pengaruhnya. Pengaruhnya nyata tidak hanya dalam hidup Gereja partikular Asia yang masyarakatnya pluri-religius, melainkan juga merambah Gereja universal. ${ }^{7}$ Gerakan praksis dialog interreligius telah

5 Lihat hasil sidang paripurna Federation of A sian Bishops' Conferences (FABC) yang pertama di Taipei, pada 1974.

6 Lihat hasil siang paripurna Bishops' Institute for M issionari A postolate (BIMA) yang pertama, pada 27 Juli 1978, di Baguio City, Filipina.

7 Di Asia teologi dialog mencapai perkembangan sangat penting ketika berlangsung sidang "Konsultasi Ekumenis Gabungan" yang diselenggarakan oleh CCA (Christian Conference of A sia) dan FABC (Federation of A sian Bishops' Conferences) di Singapore pada 5-10 Juli 1987, dengan tema "Living and Working Together with Sisters and Brothers of Other Faith" (Iih. FA BC Paper N 0. 49, 1987). Perkembangan sangat penting itu bukan terutama karena telah diupayakannya sistematisasi teologi dialog, melainkan mulai diusahakan penjabaran pastoralnya dalam Gereja-gereja Asia. Selain Gereja Asia, warna dialog juga telah melanda Gereja-gereja Afrika dan Eropa. Di Afrika hal ini tampak dalam proposal para Uskup Afrika Timur, AMECEA (The A ssociation of $\mathrm{M}$ ember E piscopal Conferences of East A frica). Lih. "A Synod Cooked in an A frican Pot," Catholic International 3(1Januari 1992): 24-36. Sementara di Gereja Eropa, tema dialog jelas menjadi bagian deklarasi sinode Uskup-uskup Eropa yang berlangsung pada Desember 1991 (bab III). Lih. L'O sservatore Romano 51/ 52 (23-30 Desember 1991). A neka aktivitas terbaru yang dilakukan oleh Gereja-gereja di A frika, Eropa dan A merika juga menunjukkan perkembangan penting dalam teologi dialog, di antaranya dialog dengan Islam yang berlangsung pada N ovember 2009 di Vatikan. 
dan sedang dirintis di mana-mana mulai dari tingkat yang paling kecil yakni keluarga, kampung, dan desa sampai tingkat yang lebih luas, yaitu tingkat nasional dan internasional. Dengan praksis semacam itu, Gereja makin hari makin menampilkan ciri khas penghayatan kehidupan iman yang merangkul, menyapa, dan terbuka.

Prestasi gemilang Konsili Vatikan II ialah pembaruan pandangan mengenai Gereja dari “institusi keselamatan" menjadi "sakramen keselamatan." Gereja sebagai sakramen keselamatan memaksudkan demikian: Gereja hadir sebagai tanda sekaligus sarana yang mewujudkan kesatuan mesra manusia dengan Allah dan persatuan seluruh umat manusia. ${ }^{8} \mathrm{Da}-$ lam pengertian ini keselamatan dilukiskan tidak pada institusi Gereja, melainkan pada "kesatuan manusia dengan Allah" dan "persatuan umat manusia" yang ditampilkan oleh umat Allah. ${ }^{9}$

Paham ini memiliki konsekuensi teologis baru, yaitu bahwa semua manusia dipanggil menjadi umat Allah yang baru, ${ }^{10}$ namun tidak semua tergabung dan terarah kepada-Nya dengan cara yang sama. ${ }^{11}$ Sejauh hidup mereka menampilkan segi-segi kesatuan umat manusia dengan Allah dan persatuan dengan sesamanya, mereka juga telah menghadirkan keselamatan itu sendiri.

Pandangan di atas memberikan arus perkembangan positif dalam hidup Gereja. Gereja melangkah lebih maju, menggalang dialog interreligius untuk bersama-sama mewujudkan kesatuan umat manusia dengan Allah dan persatuan antarmanusia, sebab Gereja Katolik tidak menolak apa yang benar dan suci dalam agama-agama. ${ }^{12}$ Dengan tulus Gereja mengakui bahwa dalam agama-agama ada banyak hal yang berbeda dengan imannya, namun apa yang benar dan suci itu diakui pula sebagai “tidak jarang memantulkan cahaya kebenaran yang menerangi semua

8 Lihat Konstitusi Dogmatis tentang Gereja, Lumen Gentium (selanjutnya: LG), 1.

9 LG, 9.

10 LG, 13.

11 LG, 15 dan 16.

12 LG, 16. Lihat juga terutama Pernyataan tentang Hubungan Gereja dengan Agamaagama bukan Kristen, N ostra A etate (selanjutnya: NA), 2. 
manusia." 13

Dalam N ostra A etate artikel 1, Konsili Vatikan II memberikan pertanggungjawaban historis sekaligus teologis mengapa Gereja berdialog. ${ }^{14} \mathrm{Da}$ Iam alasan historis, Gereja menyimak tanda-tanda zaman bahwa dewasa ini umat manusia semakin disatukan satu sama lain. Mengenai alasan teologis, Gereja menegaskan tiga hal: pertama, tugas dan tanggungjawabnya sebagai sakramen keselamatan harus memajukan persatuan dan kasih di antara umat manusia berdasarkan kasih Sang Pencipta; kedua, Gereja percaya bahwa bangsa-bangsa sesungguhnya hanya membentuk satu komunitas karena semuanya mempunyai asal dan tujuan yang sama, yaitu Allah; ketiga, umat manusia sendiri telah Iama menantikan jawaban-jawaban dari agama-agama atas aneka persoalan hidup yang mendasar, seperti tentang hakekat manusia, arti dan tujuan hidup, apa yang baik dan dosa, dan seterusnya.

Alasan-alasan di atas menjadi dasar perlunya mengapa Gereja harus membangun penghayatan iman yang dialogal, menyapa, dan bekerjasama. Tetapi sampai saat ini pengembangan komunikasi iman lewat dialog interreligius masih sebatas sopan santun belaka. ${ }^{15}$ Dialog interreligius digalang, tetapi sering hanya untuk mencegah kecurigaan, ketersinggungan satu sama lain. Gerakan ekumenis juga tidak lebih dari

13 NA, 2

14 Rincian gagasan dokumen $\mathrm{N}$ ostra A etate dan yang lain dengan singkat dapat disimak dalam B.A. Pareira, "Evangelisasi dan Dialog dengan Agama-agama N on Kristen," Forum 16 (1990): 4-11.

15 Penilaian ini dikatakan bukan semata dari menyimak fakta, melainkan dipikirkan sebagai konsekuensi logis dari "kekaburan" eklesiologi Lumen G entium, yaitu dobel eklesiologi (komunio para uskup dengan ketuanya Paus dan komunio sebagai paham dasar Gereja sebagai umatAllah). Prof. Tom Jacobs menegaskan bahwa kekaburan eklesiologi ini menyebabkan ekumene dan dialog macet hanya dalam bentuk-bentuk lahiriah dan tidak melangkah pada apa yang fundamental mencakup komunikasi iman umat. Maksudnya, karena komunio selain merupakan pengertian Gereja sebagai U mat Allah juga menunjuk pada kerekanan para Uskup dengan ketuanya Paus, dialog seringkali dipraktikkan hanya sejauh dalam restu hierarki dan kerap terbatas dalam wujud pertemuan-pertemuan lahiriah, dan kurang menyentuh komunikasi yang lebih dalam. Lih. Tom Jacobs, Gereja M enurut V atikan II (Yogyakarta: Kanisius, 1987), hlm. 60-61. 
upaya kompromistis. ${ }^{16}$ Komunikasi iman yang real dan konkret hingga melahirkan suatu bentuk penghayatan dialogal yang membebaskan, belum sungguh-sungguh dijalin.

Aloysius Pieris melihat bahwa ciri kehidupan iman yang dialogal dari umat Allah merupakan tuntutan mutlak agar dapat dikembangkan Gereja setempat yang sungguh-sungguh otentik. Pengamatan Pieris ini memaksudkan bahwa teologi dialog tidak hanya sekedar menjelaskan penghayatan iman secara dialogal dengan umat beragama lain, melainkan juga memiliki dimensi transformatif, yaitu mengembangkan otentisitas penghayatan iman umat Kristen dan membebaskannya dari keterasingan berada di tengah-tengah umat beragama lain. ${ }^{17}$

Dialog interreligius tidak tanpa persoalan. Persoalan pertama yang langsung terkenaialah berkaitan dengan misi Gereja. Dikhawatirkan semangat dialog justru mengendurkan semangat misioner Gereja. ${ }^{18} \mathrm{~K}$ arena perkembangan teologis baru tentang dialog interreligius, tugas pewartaan Gereja kepada umat manusia yang belum mengenal Kristus, terasa membingungkan, ${ }^{19}$ sebab apabila diakui di luar Gereja ada keselamatan, apa fungsi pewartaan kabar keselamatan yang kita bawa? Bukankah dengan karya misioner kita, kita malah akan mengganggu hati nurani mereka?

16 Memang harus diakui bahwa kondisi kehidupan beragama di Indonesia pada masamasa tertentu masih ada dalam kerawanan. Simak misalnya majalah Tempo XX: 37 (10 N ovember 1990) yang mengambil temalaporan utama "Problem Kerukunan Beragama" (yang pada waktu itu muncul kasus tabloid M on itor); juga Tempo XXII : 42 (19Desember 1992) dengan tema utama "A gama dan Keretakan" (karena ada fakta-fakta pembakaran Gereja, isu pembakaran AI Qur'an, dst.). Di akhir milenium, menjelang kejatuhan rezim OrdeBaru dan sesudahnya, Gereja Indonesia benar-benar mengalami mendung kelabu yang pekat menyusul aneka kerusuhan yang menyesakkan di hampir semua wilayah Indonesia, mulai dari Ambon hingga Situbondo, Aceh sampai wilayah Ketapang, Jakarta.

17 Aloysius Pieris, An A sian Theology of Liberation (Quezon City, Philippines: Claretian Publication, 1988), pp. 61-62.

18 Lih. H ak Kerukunan 12: 72-73 (September-N opember 1991): 5-6.

19 Yves Congar, salah seorang anggota komisi untuk misi di Vatikan II, mengatakan: "Teks A d G entes ditulis untuk situasi negara-negara Kristiani yang mengutus misionarismisionaris ke daerah-daerah yang disebut daerah misi... M emang pengaruh A d G entes mengatasi maksud-maksud ini...." dikutip oleh Tom Jacobs, "Misi dan Kristologi," Orientasi Baru 5 (1991): 69. 
Kardinal A rinze, Ketua Dewan Kepausan untuk Dialog Interreligius, menunjukkan beberapa persoalan yang diakuinya sangat santer ${ }^{20}$ Bagaimanakah dialog dengan agama-agama dan tugas pewartaan Injil dapat berjalan bersama-sama, sedangkan maksud pewartaan ialah agar orang menerima Injil dan diinkorporasikan kedalam Gereja melalui permandian? Dikatakan bahwa dialog merupakan bagian tak terpisahkan dari pewartaan, tetapi persoalannya jika demikian apakah artinya dialog. Adakah dialog itu sungguh-sungguh merupakan dialog yang benar jika dimaksudkan demi pewartaan? Adakah dial og dengan agama-agama itu merupakan evangelisasi atau bila tidak, termasuk apa?

Persoalan kedua menyangkut dialog interreligius sebagai komunikasi iman. Benarkah komunikasi iman sejak Konsili Vatikan II sampai sekarang masih sebatas sopan santun belaka? Sampai sejauh manakah Gereja menaruh perhatian terhadap masalah komunikasi iman lewat dialog interreligius? A pakah sesungguhnya yang dikatakan Gereja Katolik sejak Konsili Vatikan II sampai sekarang (D ialogueand Proclamation 1991) mengenai dialog interreligius sebagai komunikasi iman? Demikianlah beberapa pertanyaan krusial dalam studi dialogalitas interreligius.

Melihat beberapa persoalan di atas, dapat dikatakan bahwa dialog interreligius masih dalam proses pencarian identitasnya. Pembahasan sistematis tentangnya sebagaimana sering dijumpai masih dalam bingkai konteks mencari alternatif yang pas untuk sebuah sistem teologi dialog. ${ }^{21}$

20 Lih. L'O sservatore Romano, no. 26 (1 July, 1991): 1. Kardinal Arinze mengatakannya menyusul terbitnya dokumen dari dua discasteria, yaitu Sekretariat Dewan Kepausan untuk Dialog Interreligius dan Kongregasi untuk Evangelisasi Bangsa-Bangsa, D ial ogue A nd Proclamation, 1 Juli 1991.

21 Beberapa terbitan tentang tema dialog interreligius, misalnya Harorld Coward, Pluralism, Challenge to W orld Religions (New York: Orbis Books, 1985); David Tracy, The A nalogical Imagination. Christian Theology and The Culture of Pluralism (New York: Crossroad, 1981); Wilfred Cantwell Smith, Toward a W orld Theology: Faith and The Comparative History of Religion (Philadelphia: Basingtoke and the Westminster Press, 1981); buku-buku seri dari O rbis Books, New York: Raimundo Panikkar, The U nknown Christ of Hinduism: Towards an Ecumenical Christophany (1981); Leonard Swidler (Ed.), T oward a U niversal Theology of R eligions (1987); John Hick and Paul F. Knitter (Eds.), The M yth of Christian Uniqueness: Toward a Pluralistic Theology of Religions (1987); David Lochhead, The D ialogical Imperative(1988); Aloysius Pieris, LoveM eets W isdom: A Christian Experience of Buddhism (1989); dan Iain-lain. 
Dalam khasanah studi teologis berbahasa Indonesia, pembahasan tema ini telah dirintis oleh beberapa teolog Katolik, diantaranya:

Robertus Hardawiryana dalam beberapa tulisannya mencoba memberikan pengantar umum untuk memahami beberapa dokumen Gereja. ${ }^{22}$ Tetapi perhatiannya yang utama sesungguhnya terletak pada usaha mencari dan merumuskan pola Gereja yang tepat dan relevan dalam masyarakat pluri-religius di Asia. Persoalan tajam yang dilontarkannya ialah "Bagaimana Gereja sebagai kawanan kecil menjalankan tugas komunikasi imannya, yang tidak untuk dirinya sendiri melainkan juga semua orang, di antara semua pemeluk agama-agama besar di Asia yang tidak akan pernah menjadi orang Kristen dan yang (bukan namun!) toh dicintai Allah, Allah yang sama yang diwartakan Yesus Kristus sebagai Bapa semua orang." ${ }^{23}$ Perhatian istimewa Hardawiryana terhadap dialog interreligius berada dalam bingkai konteks eklesiologi Asia dan bagai mana penjabaran pastoral nya. Sebagai ganti istilah "dialog interreligius" beliau lebih kerap menyebutnya "dialog pluri-religius."

Tom Jacobs memberikan sumbangan dasar-dasar kristologis mengenai persoalan dialog dengan agama-agama bukan Kristen. Persoalan yang dibahasnya berpangkal pada pertanyaan fundamental "apakah arti maklumat Kristus untuk misi di tengah agama-agama lain." ${ }^{24}$ Keprihatinan Prof. Dr. Jacobs tidak langsung menyentuh Gereja Asia, namun demikian paham-paham dasar kristologis yang diajukannya dapat melengkapi upaya pembicaraan tentang komunikasi iman di tengah-tengah agama-agama besar di Asia.

22 Beberapa tulisannya tentang tema ini misalnya, "Ensiklik Redemptoris Missio Dokumen Dialog Proklamasi" (makalah yang dipresentasikan pada sidang KWI 1990); "Dialog dan Proklamasi. Suatu Tinjauan" (makalah ilmiah yang hendak diterbitkan Spektrum), dan "Beberapa Pokok Pemikiran Sidang Pleno FABC V, Lembang, 17 - 27 Juli 1990 yang Relevan bagi Perkembangan Gereja di Indonesia," Spektrum XIX, nomor 2, 3, dan 4 (1991), dll. Yang terbaru yang merupakan himpunan tulisan beliau tentang tema ini ialah Gereja dan D ialog Pluri-R eligius (Yogyakarta: Kanisius, 2003).

23 Tampak dalam tulisannya: "Mengembangkan Kesadaran Ekumenis Umat Beriman," O rientasi (1972) dan "Peranan Gereja dalam Masyarakat Plurireligius di Asia," O rientasi Baru 5 (1991): 14-67.

24 Tom Jacobs, "Misi dan Kristologi," O rientasi Baru 5 (1991): 68-91. 
J.B. Banawiratma memberikan gambaran sistematis bagaimana bentuk penghayatan iman yang dialogal sekaligus transformatif dijalankan. ${ }^{25}$ Bertumpu pada gagasan Konsili Vatikan II tentang Gereja sebagai sakramen keselamatan, ia mencoba menggariskan secara sistematis bagaimana hidup Gereja harus menjadi tanda dan sarana keselamatan dalam suatu kondisi pluralisme religius. ${ }^{26}$ Sumbangan Prof. Dr. Banawiratma terletak pada ajakannya untuk berteologi fungsional, kontekstual (dan termasuk di dalamnya dialogal) di tengah-tengah masyarakat majemuk.

Berthold Anton Pareira, dengan diinspirasikan oleh J. Dupuis dan M. Dhavamony, ${ }^{27}$ melansir dokumen-dokumen mulai dari Ensiklik Ecclesiam Suam (1964) sampai dokumen tentang Dialog dan M isi (1984) dalam suatu pembahasan kompilatif mengenai evangelisasi dan dialog dengan agama-agama bukan Kristen. ${ }^{28}$ Prof. Dr. Pareira tidak bermaksud memperkenalkan dokumen-dokumen tentang dialog interreligius, melainkan berusaha memberikan sumbangan di mana dialog harus ditempatkan dalam kerangka evangelisasi dan apa hubungan keduanya.

Kendati sudah barang tentu ada aneka kontribusi penulis-penulis yang lain, ${ }^{29}$ sesungguhnya hingga saat ini belum dijumpai tulisan yang

25 Banawiratma, "Wujud Baru Hidup Menggereja: Dialogal dan Transformatif," O rientasi Baru 5 (1991), hlm. 9-13.

26 Banawiratma, "Teologi Fungsional - Teologi Kontekstual," dalam Eka Darmaputera (Peny.), Konteks Berteologi di Indonesia (Jakarta: BPK. Gunung Mulia, 1988), hlm. 47-64.

27 Jaques Dupuis, "Interreligious Dialoguein theChurch'sEvangelizing Mission: Twenty Years of Evolution of a Theological Concept;" Mariasusai Dhavamony, "Evangelization and Dialogue in Vatican II and in the 1974 Synod," keduanya dalam Rene Latourelle (Ed.), V atican II A ssessment and Perspectives (1962 - 1987) Vol. III (New York: Paulist Press, 1989), pp. 237-281.

28 Bertold Pareira, "Evangelisasi dan Dialog dengan Agama-agama bukan Kristen," Forum 18 (1990): 4-11.

29 Di samping penulis juga para praktisi dialog telah menyumbang perspektif yang kaya terhadap ranah dialog interreligius. Yang disebutkan di sini sudah barang tentu sejauh dalam jangkauan yang terbatas. Penulis-penulis itu dapat disebutkan, misalnya: A Ifons S. Suhardi, "Pekabaran Injil dalam Konteks Pluralitas Keagamaan di Indonesia;" B.S. Mardiatmaja, "H ubungan A ntarumat Aneka Beragama di Negara Pancasila," keduanya dalam Hak Kerukunan, 12 (Maret-Juli 1991); Philipus Tule, Bermisi dalam Semangat Dialog dengan Islam (makalah ilmiah yang disampaikan dalam ceramah di depan Senat Mahasiswa STFT Widya Sasana Malang, 4 Desember 1991). Dapat pula 
secara komprehensif menaruh perhatian pada upaya penggalian dokumen-dokumen Konsili Vatikan II dan Pascakonsili Vatikan II tentang dialog interreligius dengan segala pergumulan teologisnya. Yang sudah dijalankan (di antaranya oleh Pareira dan Hardawiryana) bersifat kompilatif atau terbatas untuk memberi pengantar umum monotematis dari satu dua dokumen. Studi dialog interreligius yang penulis jalankan (dalam buku DI) berminat memberi sumbangan dan mengisi ruang kosong itu. Buku ini mencoba menggali gagasan-gagasan dokumendokumen Konsili Vatikan II dan Pascakonsili Vatikan II tentang dialog interreligius secara eksploratif yang menggabungkan metode-metode deskriptif, eksplanatoris (menjelaskan rumusan-rumusan), dan mencoba meraih suatu sistematisasi pandangannya. Di samping itu, dibeberkan pula pergumulan teologis dan deskripsi wajah dialogal Gereja Asia dan Indonesia.

A pa yang dimaksud dengan dokumen-dokumen ialah mulai dari Ensiklik Ecclesiam Suam (1964), Konsili Vatikan II dan Pascakonsili Vatikan II sampai dokumen terakhir yang dikeluarkan oleh Sekretariat Dialog Interreligius dan Kongregasi untuk Evangelisasi Bangsa-bangsa, D ialogue and Proclamation (1991). Selain kedua dokumen yang disebut terdahulu, dokumen-dokumen (Konsili) yang dimaksudkan ialah Konstitusi Dogmatis tentang Gereja, Lumen Gentium, Konstitusi Pastoral tentang Gereja dalam Dunia, Gaudium et Spes, Dekrit tentang Karya Misioner Gereja, A d Gentes, dan Deklarasi tentang Sikap Gereja terhadap Agamaagama bukan Kristen, N ostra A etate. Yang termasuk dokumen-dokumen Pascakonsili Vatikan II ialah Amanat A postolik tentang Pewartaan Injil

disebut di sini penulis Islam, Johan Effendi, "Dialog A ntaragama: Bisakah M elahirkan Teologi Kerukunan?", dalam Seri Prisma II: A gama dan Tantangan Jaman (art. 1975 1984) (Jakarta: LP3ES, 1985), hlm. 168-178. Pada 13-16 Mei 2008, diadakan Pertemuan Nasional Komisi HAK-KWI di Surabaya. Pertemuan itu mengukir langkah-langkah yang bagus tentang dialog interreligius, di antaranya terdapat beberapa tulisan teol ogi dialogal, seperti “Menuju Gereja yang Ramah, Berbelarasa, dan Dialogis" (JB. Heru Prakosa), hlm. 51-56, "Gereja Berdialog, Gereja yang Harmonis" (B.A. Rukiyanto), hlm. 57-71, dan "Beriman Dialogal: Selintas Pandang Dokumen-dokumen Konsili Vatikan II dan Pascakonsili Vatikan II" (Armada Riyanto) hlm. 72-82. Belum disebut di sini para penulis dan praktisi dari kalangan Kristen maupun umat beriman lain yang memberikan kontribusi kaya dan luas tentang dialog interreligius. 
kepada Bangsa-bangsa, Evangelii N untiandi (1975), Ensiklik Redemptor H ominis (1979), Dokumen Sekretariat tentang Sikap Gereja terhadap Penganut Agama-agama lain, Dialogue and M ission (1984), Ensiklik Redemptoris M issio (1990), dan Dokumen Sekretariat tentang Dialog dan Pewartaan, Dialogue and Proclamation (1991).

Sudah barang tentu tahun 1991 bukanlah tahun terakhir dikeluarkannya dokumen yang berkaitan dengan dialog interreligius. Masih ada banyak lagi dokumen-dokumen yang mengalir. Umumnya berupa Reflection, Letter, M essage, D eclaration, Homily, Intervention atau yang sejenis yang mengindikasikan tema tertentu untuk suatu konteks wilayah dan perhelatan maksud acara tertentu dengan audiens tertentu pula yang berasal dari Presiden Dewan Kepausan untuk interreligius dialog maupun Presiden Kongregasi Kepausan yang terkait atau juga berasal dari hasil akhir sebuah pertemuan internasional. ${ }^{30}$ Tetapi, sebagai sebuah dokumen yang memiliki kewibawaan otoritatif, D ialogueand Proclamation (1991) dapat disebut sebagai puncaknya yang terpenting.

Yang hendak dipaparkan ialah tesis-tesis tentang dialog. Dengan tesis, penulis memaksudkan gagasan pokok atau argumen atau dapat juga bersifat seruan, desakan, anjuran, prinsip-prinsip tentang dialog dan tema-tema yang terkait di dalamnya. Penggarapan ini bersifat menggali dan menghimpun gagasan-gagasan tentang dialog dari masingmasing dokumen. Dokumen seakan “dibiarkan” berbicara sendiri kepada kita.

30 Di antaranya: Final Declaration of A nnual Meeting of the J oint Committee for Dial ogue of thethePontifical Council for Interreligious Dialogue and thePermanent Committee of Al-Azhar for Dialogue among the Monotheistic Religions (Cairo, Egypt - Rome, 24-25 February 2009); Joint declaration of the Pontifical Council for Interreligious Dialogue and the Centre for Inter-religious Dialogue of the Islamic Culture and Relations Organisation (Tehran, Iran) at the conclusion of the sixth Colloquium held in Rome from 28 - 30 A pril 2008; Final Dedaration of Annual Meeting of the Joint Committee for Dialogue of the Permanent Committee of Al-Azhar for Dialogue among the Monotheistic Religions and the Pontifical Council for Interreligious Dialogue (Cairo, 25-26 February, 2008); Final Declaration of the participants in the Symposium on Spiritual Resources of the Religions for Peace (January 18, 2003); The Spirituality of Interreligious Dialogue (1999); Pastoral attention to traditional religions (1993), dan seterusnya. 
Mengapa mempelajari dokumen-dokumen? Penulis melihat setiap upaya untuk menyimak sampai sejauh apa kesadaran Gereja mengenai dialog interreligius, tidak bisa lain kecuali harus kembali kepada dokumen-dokumen resmi Gereja. Gereja memahami tema dialog tidak sekal i jadi. Perkembangan pengertiannya perlu disimak, sebab menyimak perkembangan pengertian Gereja pada akhirnya juga berguna untuk meraih pengertian kita sendiri. Pengertian yang benar tentang dialog interreligius diperlukan untuk pembaruan hidup Gereja di tengah masyarakat pluri-religius, masyarakat kita.

Studi ini juga mengetengahkan sebuah kajian diskursus pergumulan teologis. Sebagai sebuah diskursus, metodologi dan gagasannya sudah pasti tidak dimaksudkan otoritatif, melainkan merujuk kepada perspektif pergulatan eksistensial (sejauh menjadi milik teolognya) dan kontekstual (sejauh merupakan bagian dari peziarahan Gereja setempat).

\section{DIALOGALITAS DAN KETEGANGAN DOKTRINAL}

Diskursus dialog interreligius kerap berada dalam ketegangan doktrinal. Tidak dapat diingkari kenyataan ini membawa para teolog kepada eksplorasi perspektif baru tentang imannya. Harold Coward dalam bukunya Plural ism mencoba merangkum dinami ka pergumulan refleksi teologis dari para teolog Kristen dan Katolik. Ia menyebut pergumulan teologis itu dengan "pendekatan-pendekatan baru."

Pergumulan-pergumulan ini pada prinsipnya hendak mencari jalan keluar dari ketegangan antara sikap eksklusif dan relatif tentang konsep keselamatan oleh dan dalam Kristus. Di satu pihak mereka ingin keluar dari kungkungan eksklusivisme yang sudah tak berlaku lagi, tetapi di lain pihak, mereka tidak mau jatuh pada pemutlakan relativisme yang sangat merugikan eksistensi iman Kristiani. Pemutlakan relativisme sangat merugikan, sebab pandangan ini mengaburkan dan mengacaukan identitas agama dan iman Kristiani. Penulis mengajukan empat pergumulan (Harold Coward mengajukan tiga) yang tampil sebagai 
pergumulan-pergumulan mutakhir::31 pergumulan teosentris, pergumulan kristosentris, pergumulan eklesiosentris, dan pergumulan dialogis. Salah satu yang emblematis perihal pergumulan ini telah diurai dengan meyakinkan oleh Karl Rahner dalam terminologi "Kristen A nonim." Hans Küng menambahkan perihal makna baru yang disebut "teologi ekumenis" yang menjadi perhatian sepanjang karir teologisnya.

\subsection{Kristen Anonim}

Gagasan kristosentris Karl Rahner yang paling banyak dibicarakan ialah $\mathrm{K}$ risten an onim. ${ }^{32}$ Tetapi Harold Coward melihat bahwa pergumulan kristosentris, Kristen anonim, merupakan upaya sistematis untuk menegaskan keunikan dan universalitas Kristus sekaligus menghormati kehendak Allah untuk menyelamatkan manusia yang sifatnya universal.

Rahner menulis, jikalau di satu pihak kita memahami keselamatan sebagai sesuatu yang khas Kristiani dan di lain pihak Allah benar-benar dan sungguh-sungguh bermaksud menyelamatkan semua orang, maka kedua aspek ini tidak dapat didamaikan dengan cara lain kecuali dengan menyatakan bahwa setiap manusia sesungguhnya memang terbuka terhadap pengaruh-pengaruh rahmat ilahi yang adiduniawi; dan rahmat ilahi yang adiduniawi inilah yang memberi jal an keluar berkaitan dengan persoalan umat bukan Kristiani. Umat bukan Kristiani, karena rahmat

31 Uraian tentang bagian ini didasarkan atas $\mathrm{H}$ arold Coward, Pluralism. Challenge to W orld Religions (N ew York: Orbis Books, 1985), pp. 25-44. Pada skema uraian Harold Coward tidak dicakup pergumulan eklesiosentris, padahal bila disimak perkembangan terakhir, pergumulan eklesiosentris merupakan kemajuan tersendiri dalam dialog interreligius. Juga teolog-teolog yang hendak dibicarakan di sini tidak dikategorikan dalam salah satu pergumulan (jadi berbeda dengan penjelasan Coward). Artinya, satu dua teolog dapat memiliki dua model pergumulan seiring dengan perspektif aksentuasi refleksi teologisnya.

32 Pandangan Rahner tentang "Kristen anonim" dapat disimak dalam beberapa tulisannya: "A nonymous Christians," dalam Theological Investigations (selanjutnya: T.I.), Volume VI, pp. 390-398; "One Mediator and Many Mediations," dalam T.I. Volume VII, pp. 169-184; "Jesus in the Non-Christian Religions," dalam T.I. Volume XVII, pp. 39-50; "Anonymous and Explicit Faith," dalam T.I. Volume XVIII, pp. 52-59. Dapat juga disimak "On the Importance of the N on-Christian Religions for Salvation," dalam T.I. Volume XVIII, pp. 288-295; "Observations on the Problem of the 'A nonymous Christian'," dalam T.I., Volume XIV, pp. 280-294; G.D'Costa, "Karl Rahner's Anonymous Christian - A Reappraisal," M odern Theology 1 (1984): 131-148. 
ini, sesungguhnya tidak tanpa iman kepada Kristus. Mereka beriman kepada Kristus, tetapi secara anonim, implisit. Iman kepada Kristus inilah yang memberinya keselamatan, biar pun implisit.

Dari gagasan ini, tampak bahwa Rahner meletakkan kepentingan iman kepada Kristus sebagai syarat penebusan. Dalam tulisannya, A nonymous and Explicit Faith, ${ }^{33}$ ia menegaskan pertama-tama perlunya iman bagi keselamatan. Terhadap umat Kristiani, tidak ada masalah teologis berkaitan dengan iman kepada Kristus. Tetapi bagaimana dengan umat bukan Kristiani? Bagaimana seseorang yang dengan sadar menolak dirinya sebagai Kristiani toh masih dapat disebut sebagai orang yang tidak tanpa iman kepada Kristus? Keselamatan mengalir dari Kristus. Kalau diakui bahwa keselamatan dapat dicapai melalui agama lain, itu pasti merupakan pengalaman Kristiani anonim. Karl Rahner menyusun pemikiran kristosentrisnya dalam kaitan dengan empat tesis berikut: ${ }^{34}$

Pertama, Agama Kristiani memahami dirinya sebagai agama mutlak yang ditujukan untuk semua orang dan oleh karena itu tidak dapat mengakui agama-agama lain sebagai sama. Kemutlakannya terletak pada iman akan Kristus.

Kedua, bila Injil belum sampai memasuki sejarah kehidupan seseorang, suatu agama bukan Kristen dapat mengisi individu yang bersangkutan tidak saja dengan pengetahuan alami tentang Allah, tetapi juga dengan unsur-unsur rahmat Allah yang adiduniawi yang diberikan dengan bebas oleh Allah karena Kristus.

Ketiga, oleh karena itu orang bukan Kristiani tidak dapat dikatakan sebagai kafir, melainkan sebagai Kristen anonim.

Keempat, Gereja tidak mengganggap diri sebagai komunitas eksklusif yang memiliki satu-satunya kabar keselamatan, melainkan sebagai barisan depan sejarah dan cetusan yang konkret dari harapan Kristiani yang hadir sebagai realitas terselubung dalam agama-agama lain.

33 Lih. Karl Rahner, T.I., Volume XVI, pp. 56-57.

34 Kutipan dari Harold Coward, Pluralism: Challenge to W orld Religions, p. 38. 
Melalui keempat tesis ini Rahner mendamaikan rahmat Allah yang bersifat universal dalam menyelamatkan setiap orang dengan keunikan Kristus sebagai kriteria yang nyata dan sempurna untuk rahmat itu. Kristiani anonim juga dimungkinkan, karena sifat transenden pewahyuan diri Allah yang bebas. Wahyu dalam pengertian Rahner memaksudkan "komunikasi diri Allah." Komunikasi diri Allah bersifat bebas. Komunikasi diri Allah haruslah dilihat sebagai tindakan Allah yang menyelamatkan. Karena tindakan ini bersifat bebas, maka tindakan itu mencakup pula orang-orang yang tidak beriman secara eksplisit kepada Kristus sebagai pemenuhan komunikasi diri Allah.

\subsection{Teologi Ekumenis}

Hans Küng mencetuskan suatu diskursus tentang teologi ekumenis. Nama Ekumenisme diambil dari tulisannya untuk mengawali suatu diskusi tentang teologi dialog, Toward a $\mathrm{N}$ ew Concensus in Catholic (and Ecumenical) Theology ${ }^{35}$ dan What is True Religion?: Toward An Ecumenical Criteriology. ${ }^{36}$

Keprihatinan pada Küng sesungguhnya juga berkisar masalah dialog dengan agama-agama lain. $\mathrm{Hal}$ ini ditunjukkan dalam aneka tulisannya, misalnya Christianity and World Religions: Dialogue with M uslim. ${ }^{37}$ Keprihatinan profesor Küng berawal dari tesisnya bahwa "tiada perdamaian di dunia ini, jika tiada perdamaian di antara agamaagama"; "tiada perdamaian dalam agama-agama tanpa dialog;" "tiada dialog interreligius tanpa usaha untuk saling memahami satu sama lain tradisi agama-agama;" dan "tiada saling pengertian di antara agamaagama, bila tidak diusahakan upaya-upaya teologis yang bersifat

35 Artikel itu ditulis sebagai pembuka untuk masuk dalam diskusi mengenai "Concensus in Theology?," Journal of Ecumenical Studies 17 (Winter 1980): 1-17.

36 Dalam Leonard Swidler (Ed.), Toward a U niversal Theology of Religion (N ew York: Orbis Books, 1987), pp. 231-250.

37 Hans Küng, "Christianity and World Religions: Dialogue with Muslim," in Leonard Swidler (Ed.), Toward a U niversal Theology of Religion, pp. 192-209. Dapat juga disimak Paul F. Knitter, “Hans Küng's Theological Rubicon," in Leonard Swidler (Ed.), Toward a U niversal Theology of Religion, pp. 224-229. Tulisan Knitter ini juga menjadi dasar uraian tentang bagian ini. 
ekumenis atau dialogis." Sejarah agama-agama membuktikan kebenaran tesis ini. Dalam keprihatinan Küng, tiada hal yang lebih pahit dari pada perang yang disebabkan karena agama.38

Bila suatu teologi ekumenis atau dialogis dimungkinkan kepentingannya karena dapat menjadi cara untuk mencegah terjadinya persengketaan karena agama, timbul persoalan: apakah teologi ekumenis hanya sekedar pemecahan pragmatis? Teologi ekumenis memang dapat menjadi sekedar pemecahan praktis; akan tetapi pertanyaan fundamental yang hendak diperhatikan dalam teologi ekumenis adalah bagaimana seorang Kristiani yang meyakini agamanya sebagai kebenaran dapat menerima klaim kebenaran lain yang diyakini oleh sesamanya tanpa kehilangan identitas kebenaran agamanya. Atau, seperti yang ditegaskan Küng, apakah kriteria kebenaran suatu agama? Atau apakah yang menjadi standar untuk menilai kebenaran agama? A tau, apakah agama yang benar itu? Küng mengajukan empat posisi penilaian fundamental: 1) tiada agama satu pun benar, atau 2) hanya satu agama yang benar, sementara yang lain tidak, atau 3) setiap agama benar, atau 4) satu agama sebagai benar, yang lain ambil bagian dalam kebenarannya.

Manakah kriteria yang dapat mengantar orang Kristen pada suatu dialog dengan agama-agama lain? Pemecahan Karl Rahner dengan mencetuskan apa yang disebut teori Kristiani anonim berada pada kelompok posisi keempat. Küng menganalisis apa yang dikemukakan Rahner dengan teori Kristiani Anonim hanyalah pemecahan untuk memberi jalan keluar bahwa di satu pihak di luar agama Kristiani ada keselamatan, tetapi di lain pihak keselamatan toh tetap melekat pada Kristus. Maka, terhadap pemeluk agama lain, harus dikatakan bahwa mereka sesungguhnya Kristiani, hanya anonim (tanpa nama secara eksplisit Kristiani). Mereka Kristiani anonim sadar atau tidak sadar. Küng mengkritik pandangan ini sebagai langsung menjadi pagar bagi langkah maju menuju dialog interreligius, sebab gagasan ini mengambil titik tolak

38 Lihat The M onth (September/ October 1991): 367, perihal introduksi tentang "Faith meets Faiths." 
superioritas Kristiani ${ }^{39}$ Ia mendesak suatu perlakuan adil bahwa orang bukan Kristiani harus dipandang sebagaimana adanya, tidak dipandang sebagai seolah-olah Kristiani. Lantas apakah yang menjadi dasar sikap orang Kristiani dalam membangun teologi dialog?

Menurut Küng titik tolak dialog harus berawal dari sikap bahwa kebenaran tidaklah merupakan monopoli Kristiani, sebab kebenaran agama tidak sekedar perumusan-perumusan iman atau teori-teori tentang Allah, Wahyu, manusia, alam, dosa, Kitab Suci, dan seterusnya. Kebenaran bukanlah sekedar proposisi-proposisi yang secara teologis sahih. Kebenaran agama menyentuh praksis, pengalaman-pengalaman personal, kesaksian pembebasan, pencerahan, dan perwujudan cinta. Dengan demikian kebenaran di sini bukanlah sekedar benar secara rasional, melainkan juga benar dalam arti baik. Seorang Kristiani dan seorang Islam yang benar sekaligus adalah seorang Kristiani dan seorang Islam yang baik dalam kesaksian hidupnya. Dengan ini sesungguhnya tidak ada alasan untuk menekankan eksklusivisme suatu kebenaran agama. Itulah sebabnya Küng mengusulkan "kriteria etika umum" untuk membangun suatu dialog interreligius dengan apa yang disebutnya sebagai ciri humanum. ${ }^{40} \mathrm{Kebenaran}$ dengan ciri humanum berarti kebenaran yang bersifat manusiawi. Kriteria ini dikatakannya berlaku untuk semua agama.

Teologi ekumenis model Küng dapat "menyenangkan" semua pihak, tetapi posisi sebuah refleksi tentang Sabda Tuhan yang secara spesifik menjadi milik tradisi agama Kristiani menjadi kurang jelas. Idealisme bahwa mesti terdapat "kriteria etika umum" yang secara universal melegakan semua pihak berada pada tataran etis, tetapi agak sukar dibayangkan bila halnya harus pula menyentuh wilayah teologis. Artinya, ketika masing-masing umat beragama diminta untuk tidak saling bertengkar,

39 Hans Küng, "What is True Religion? Toward an Ecumenical Criteriology," in Leonard Swidler (Ed.), T oward a U niversal Theology of Religion, pp. 235-237.

40 Mengenai kriteria kebenaran ini diuraikan dalam Hans Küng, "What IsTrueReligion? Toward an Ecumenical Criteriology," in Leonard Swidler (Ed.), Toward a U niversal Theology of Religion, pp. 239-243. 
kriteria etis pemahaman kebenaran masing-masing tradisi agama harus secara etis tidak boleh eksklusif. Hal itu mungkin masuk akal. Tetapi, tata etis yang demikian tentu agak sukar dibayangkan apabila hendak dibawa kepada wilayah yang langsung bersentuhan dengan kebenarankebenaran misteri iman tentang keselamatan. Usulan Küng sepertinya mereduksi refleksi teologis yang menerjemahkan Sabda Tuhan kepada refleksi etis ekumenis.

\section{DIALOGALITAS DAN WAJAH PASTORAL GEREJA INDONESIA}

Studi dialogalitas (interreligius) tidak dapat dipisahkan dari loronglorong pengalaman nyata pastoral Gereja partikular. Dialogalitas adalah ciri dan karakter Gereja lokal, Gereja partikular. Gereja Indonesia sudah lama menghadirkan sikap-sikap dialogal. Hal ini antara lain tercermin secara meyakinkan dalam N ota-n ota Pastoral Konferensi Waligereja Indonesia (KWI). ${ }^{41}$ Saat menyimak N ota Pastoral 2003, 2004, dan 2006, kita menemukan tekad indah Gereja Indonesia dalam mendefinisikan dirinya sebagai "Sahabat bagi semua." Konsekuensi dari tekad ini ialah bahwa Gereja meyakini dialog sebagai panggilan perenialnya yang perlu direspon terus-menerus. Dialogal itas Gereja Indonesia tampak secara konkret dalam partisipasi aktif Gereja dalam membangun dan menciptakan "societas dialogal." 42

Dialogalitas adalah ekspresi kodrati manusia. Keindahan hidup manusia terletak pada ekspresi kebersamaannya. Sebuah kesendirian adalah kenaifan. Kebersamaan yang paling indah berada dalam ranah dialogal kehidupan. $\mathrm{N}$ ota $\mathbf{2 0 0 6}$ merincinya secara ringkas dal am aktivitasaktivitas "belajar, berdiskusi, bergerak dan berkolaborasi bersama." Kondisi kemiskinan di Indonesia [juga] hanya dapat diubah apabila kita

41 Selanjutnya disebut $\mathrm{N}$ ota dengan menambahkan "tahun" untuk menujukkan waktu dikeluarkannya Nota Pastoral, disusul dengan "angka" untuk menunjukkan nomor artikel dalam Nota Pastoral tersebut.

42 Bagian ini merujuk pada tulisan penulis tentang “ $N$ ota M eretas Jalan Societas Dialogal: Pembacaan Etis-filosofis N ota Pastoral KW I," Spektrum 34 (2007): 11-44. 
bersama-sama mempunyai kepedulian dan mengusahakannya.${ }^{43} \mathrm{Ketika}$ para Uskup memiliki kesadaran "tidak dapat bekerja sendirian," hal tersebut memiliki makna yang sangat mendalam. ${ }^{44}$ Kodrat sosial manusia benar adanya karena dari "A-Z" (dari awal hingga akhir) keseharian hidup kita dipenuhi dengan aneka aktivitas kolaborasi.

Dialogalitas memiliki keprihatinan bersama. Ciri khas societas dialogal adalah menaruh keprihatinan bersama. Keadaban adalah perkara tata hidup bersama yang mengatasi perhitungan mayoritas minoritas. Ketika disinyalir bahwa kita memiliki keprihatinan yang mendalam berkaitan dengan merosotnya keadaban publik di segala bidang, itu adalah perkara bersama. "Berbagai masalah yang timbul di bidang ekonomi, agama, hukum, kebudayaan, pendidikan, lingkungan hidup alami dan manusiawi [yang] dilihat sebagai akibat dari keburaman dunia politik bangsa [adalah keprihatinan bersama]." ${ }^{45}$ Secara konkret keprihatinan yang sama dikatakan kembali dalam N ota 2004 :

Masyarakat Indonesia berada dalam masalah yang serius. Masalah serius yang kita hadapi bersama adalah persoalan rusaknya keadaban publik (public civility)... Hidup tidak lagi sesuai dengan nilai-nilai budaya dan cita-cita mulia kehidupan berbangsa. Hati nurani tidak dipergunakan, perilaku tidak dipertanggungjawabkan kepada Allah dan sesama. ${ }^{46}$

Disamping itu, N ota 2006 menyebut pula keprihatinan mendalam berkaitan "ironi kontradiktif" kehidupan bangsa kita, yaitu miskin di tengah kemelimpahan dan lapar di lumbung beras.

Dialogalitas tidak menafikan partisipasi siapa pun, terutama warga biasa, rakyat miskin. Dalam konteks pembangunan ekonomi yang berorientasikan kesejahteraan bersama, berlaku mutlak prinsip tidak menafikan peran kehadiran siapa pun. N ota 2006 meletakkan potensi

\footnotetext{
43 N ota $2006,13$.

44 N ota $2003,2$.

$45 \mathrm{~N}$ ota $2003,5$.

46 N ota $2004,2-3$.
} 
partisipasi ekonomi warga biasa sebagai salah satu komponen utama pembangunan ekonomi nasional. Prinsip ini menggarisbawahi pentingnya sebuah kebijakan agar mengokohkan elemen-elemen ekonomi berskala kecil tetapi menjangkau kesejahteraan yang lebih luas. Tidak hanya terjebak dalam penekanan yang berlebih pada investasi global. ${ }^{47}$

Dialogalitas memiliki pondasi prinsip kebenaran dan keadilan. Jika politik dimaknai sebagai upaya untuk menata kehidupan bersama, aktivitas berpolitik sesungguhnya adalah aktivitas dialogal. Mustahil politik tanpa dialog. Tetapi, politik yang benar adalah aktivitas dialog dengan pondasi kokoh prinsip kebenaran dan keadilan. Sayang, prinsipprinsip itu kerap dilindas. ${ }^{48}$

Dialogalitas bermakna mendalam ketika societas saling membantu dalam keanekaragaman. Salah satu ungkapan "saling membantu" tidak mesti berupa sebuah bentuk uluran tangan belas kasih. Konsep dialogalitas menegaskan konsep komunikasi kepercayaan. Ajaran Sosial Gereja menyebut konsep itu sebagai subsidiaritas. Orang kerap merasa terbantu, justru ketika mendapatkan kepercayaan. N ota 2003 menegaskannya: “Menjalankan prinsip subsidiaritas berarti menghargai kemampuan setiap manusia, baik pribadi maupun kelompok untuk mengutamakan usahanya sendiri, sementara pihak yang lebih kuat siap membantu seperlunya." 49 Tidak hanya subsidiaritas, dalam societas dialogal, prinsip solidaritas juga sangat ditekankan.

Solidaritas adalah kesetiakawanan untuk bersama-sama melihat persoalan, mencari dan merancang jalan keluarnya, melaksanakan dan mengevaluasi menurut tolok-ukur kesejahteraan bersama. Prinsip solidaritas adalah kekuatan warga untuk mengorganisir diri menjadi daya gerak sosial, ekonomi, dan politik. ${ }^{50}$

\footnotetext{
47 N ota $2006,8$.

$48 \mathrm{~N}$ ota $2003,6$.

$49 \mathrm{~N}$ ota 2003, 17; lihat juga $\mathrm{N}$ ota 2006, 31.

$50 \mathrm{~N}$ ota $2006,28$.
} 
Sudah menjadi bagian kehadiran bangsa Indonesia, bahwa bentukbentuk aktivitas solider sudah terungkap dalam hidup sehari-hari yang mengatasi sekat-sekat suku, daerah, tingkat pendidikan, dan lain-lain.

Dialogalitas mencegah kesenjangan budaya. Kesenjangan budaya adalah keburukan, berupa kebiasaan hidup dan pola berpikir yang tidak menampilkan orientasi kepentingan jangka panjang. N ota 2006 merincinya dalam aneka tindakan yang menghambur-hamburkan sumberdaya ekonomi, uang, jabatan, dan waktu. A pa yang merupakan sebuah kebiasaan buruk kerap merupakan produk egoisme. Dalam jalan pikiran ini, dialog dan persahabatan menjadi aktivitas yang efektif untuk merevisinya. ${ }^{51}$

Dialogalitas mencegah kenaifan memandang orang lain sebagai ancaman. Dewasa ini makin disadari betapa konkret keteganganketegangan yang terjadi di dalam masyarakat. N ota 2004 mengakui fenomena ketegangan itu:

Kita tetap berprihatin dengan hal-hal yang baru tetapi sungguh tidak baik. Dengan mata telanjang dapat diamati kemunculan tegangan-tegangan baru dalam badan-badan publik penyangga demokrasi, keraguan dan kegelisahan dalam sektor/ komunitas bisnis, demikian pula kerisauan akan masa depan bangsa dan ketegangan-ketegangan dalam dan di antara komunitas-komunitas masyarakat warga. ${ }^{52}$

Societas dialogal menegaskan pentingnya aktivitas dialog. Barangkali tidak berlebihan bila dikatakan bahwa N ota Pastoral KWI hendak menggariskan promosi ranah dialogalitas di dalam tata hidup masyarakat. Masyarakat yang cerdas adalah masyarakat yang berdialog.

Dialogalitas adalah rasionalitas. Makna mendalam dialogalitas adalah rasionalitas. Artinya, ketika disposisi duduk bersama, saling mendengarkan dan berdialog dimungkinkan, terjadi gagasan-gagasan rasional yang menggarap seluk-beluk perbaikan kehidupan sehari-hari. $\mathrm{N}$ ota 2004 menempatkan rasionalitas pada perbaikan poros-poros

51 N ota $2006,14 d$.

52 N ota $2004,7.2$. 
pembangunan ruang publik yang menjadi salah satu elemen penting kesejahteraan bersama. Kebalikannya, ketika tidak ada dialog rasional, yang ada adalah kenaifan.

Dialogalitas adalah persahabatan yang mengatasi sekat-sekat pembatas. Bangsa Indonesia memiliki sejarah persahabatan para Pendirinya yang terpatri secara konkret dalam penerimaan Pancasila sebagai ideologi bangsa. Kesadaran ini perlu terus ditumbuhkembangkan dalam hidup sehari-hari dalam aktivitas persahabatan tanpa pembatas. Bersahabat berarti "menyeberang," berkehendak baik, menginginkan untuk berubah. N ota 2003 melukiskan pengharapan bahwa masih ada banyak warga negara yang berkehendak baik untuk mengusahakan perubahan. Pengharapan di masa depan merupakan produk dialog. Keyakinan bahwa masih ada banyak orang yang berkehendak baik menumbuhkan kesadaran kita memiliki banyak sahabat. Menjalin persahabatan hanya akan terjadi ketika orang melakukan "penyeberangan” berupa komunikasi yang menyapa, menyentuh, yang tak bertumpu pada kepentingan sendiri.

Societas dialogal mempromosikan hukum-hukum dan kebijakan non-diskriminatif. Hukum yang adil menegaskan tatanan baru hidup bersama, menepis segala kemungkinan diskriminatif terhadap yang lemah, kecil, terpencil. Societas dialogal membuka segala kemungkinan partisipasi yang menjangkau keadilan bagi semua, keadilan yang tidak disempitkan dalam paradigma utilitarian, the greatest happiness for the greatest number. Prinsip mayoritas minoritas merupakan prinsip yang dalam ranah kehidupan bersama kita, kerap menepikan peran-peran mereka yang lemah. Gereja Indonesia tidak mau mengikuti pola bertindak seperti ini:

Ketika masyarakat ditawari praksis "yang kuat yang menang," Gereja memperlihatkan melalui perkataan dan perbuatan bahwa "yang kecil, lemah, miskin dan tersingkir harus didahulukan." Gereja perlu terusmenerus, tanpa mengenal lelah, menyuarakan bahwa hukum yang adil harus berlaku untuk semua, dan tidak boleh memihak pada kel ompok tertentu. Inilah salah satu unsur terpenting penegakan hukum. Untuk 
itu struktur hukum harus melindungi kepentingan orang kecil, lemah, miskin dan tersingkir, melalui kebijakan-kebijakan publik..$^{53}$

Dalam dialogalitas, sahabat adalah "aku yang Iain." Prinsip persahabatan mengenal cara pandang bahwa orang lain sesungguhnya adalah "aku yang lain." Dalam cara pandang seperti itu, kecemasan orang lain adalah kecemasanku. Demikian juga kegembiraannya. Indonesia saat ini berada di masa-masa sulit, karena sebagian orang menderita kekurangan makan secara mengenaskan, sebagian yang lain menghabiskan banyak dana, mengalami rupa-rupa penyakit karena terlalu banyak makan. Ketika anak balita di sebuah perkampungan kecil di Cilincing, Jakarta Utara, meregang perutnya karena keluarga tidak mampu membeli makanan, di seberang jalan lainnya di sebuah distrik pusat bisnis sebagian orang menghabiskan puluhan juta untuk program diet. Diperlukan cara pandang bahwa mereka yang miskin, yang kekurangan makan sesungguhnya adalah "aku yang lain," yang karenanya aku perlu bertindak memberi mereka makanan. N ota 2006 mencatat angka menyesakkan dari mereka yang butuh makanan:

Di tahun 2005, jumlah bayi yang lahir dengan kondisi berat badan rendah karena kurang gizi, misalnya, mencapai 350.000, sedangkan bayi di bawah lima tahun (balita) yang menderita busung lapar sebanyak 1,67 juta. Jumlah balita penderita busung lapar itu meningkat menjadi 2,3 juta pada tahun 2006, dan pada tahun yang sama jumlah kematian ibu yang melahirkan adalah 307 per 100.000 kelahiran. Itu berarti, di Indonesia dalam setiap 1 jam terdapat 2 ibu meninggal ketika sedang bersalin. ${ }^{54}$

Dialogalitas membangkitkan tanggung jawab bersama terhadap lingkungan hidup manusia. Societas dialogal memandang ruang lingkup hidup manusia sebagai tanggung jawab bersama; artinya, kesadaran bahwa kerusakan lingkungan yang demikian hebat semestinya menjadi keprihatinan bersama yang lantas mendapat penjabaran tindak lanjut kebijakan-kebijakan yang efektif. Catatan tegas diberikan oleh N ota 2004 
perihal pembalakan liar hutan-hutan kita serta kehancuran lingkungan:

Kerusakan lingkungan sudah sampai tahap membahayakan hidup manusia. Salah satu faktor penting yang menyebabkan kerusakan lingkungan adalah pembabatan hutan. Sejak tahun 1985, terjadi pembabatan hutan sebesar 1.6 juta hektar per tahun dan pada tahun 1997 meningkat tajam menjadi 2.83 juta hektar per tahun... Kerusakan itu sudah mengakibatkan kerusakan lingkungan baru. Bukan hanya pohon-pohon yang hancur, tetapi iklim pun terpengaruh oleh kerusakan itu. Selain pembabatan hutan, masih banyak faktor lain yang menyebabkan kehancuran lingkungan, misalnya pembuangan limbah-limbah beracun, eksploitasi sumber-sumber dayaalam yang tanpa kendali. ${ }^{55}$

Dalam societas dialogal, dimungkinkan gerakan efektif, membangun jaringan luas. Tidak mungkin sendirian bekerja. N ota 2006 melukiskan bahwa ketika berbagai tantangan pembangunan ekonomi yang berkeadilan begitu besar, diperlukan aneka model gerakan efektif, gerakan yang melibatkan semua, gerakan yang memungkinkan terciptanya aneka jaringan yang kokoh. Sebuah gerakan tidak mungkin terjadi tanpa konsep-konsep visi tentang societas dialogal. Dalam konteks itu, N ota 2006 menuliskan beberapa prioritas yang dimaksud, antara lain membangun

... gerakan untuk memenuhi kebutuhan dasar warga masyarakat yang miskin, bukan dengan program dan proses yang membuat mereka semakin tergantung, tetapi melalui upaya-upayayang membuat potensi dan energi ekonomi mereka muncul serta bergerak; ... gerakan bersama merekayang berkehendak baik dan semua pihak, baik pemerintah maupun dunia usaha, untuk membentuk jaringan usaha-usaha kecil dan mikro yang melatih serta menghadirkan lapangan kerja bagi mereka yang tidak terampil dalam masyarakat; ... gerakan untuk melestarikan lingkungan sebagai upaya ekologis yang tidak boleh diabaikan dalam usaha peningkatan kesejahteraan ekonomi; ... semua gerakan itu dapat menjadi gerakan yang handal dan berkelanjutan apabila didukung oleh gerakan para cerdik-pandai yang terus-menerusmelakukan kajian kritis atas berbagai cara berpikir dan praktik berekonomi yang berlangsung

55 N ota $2004,6.3$. 
dewasa ini. Tujuannya untuk menemukan gagasan, cara berpikir dan praktik ekonomi baru yang lebih berorientasi pada kaum miskin dan lemah serta cita-cita kesejahteraan bersama. ${ }^{56}$

Dialogalitas mengenal kesadaran introspektif: pembenahan mulai dari rumah sendiri. Dialogal itas selain konkret dalam aktivitas berunding, bernegosiasi, juga dalam mengembangkan kesadaran introspektif. Kesadaran ini merupakan sebuah langkah konkret untuk mulai mewujudkan kehendak baik. Kehendak baik pertama-tama harus mulai diwujudkan di rumah sendiri.

Dialogalitas membutuhkan bahasa yang merangkul. Dengan "bahasa" tidak dimaksudkan sekedar tutur kata melainkan budaya, mentalitas, sikap-sikap negosiatif yang menyambut dan menghargai. Bahasa yang demikian juga mengandaikan kepercayaan bahwa banyak orang memiliki kehendak yang baik dan tekun untuk mengupayakan tata hidup yang benar. ${ }^{57}$ Karena itu harapan, ajakan, dan dorongan diajukan oleh Gereja Indonesia untuk memperjuangkan kesejahteraan bersama. Pertobatan membutuhkan cetusan kreativitas dialogal untuk membangun ekonomi yang berkeadilan. A pa yang disebut sebagai dorongan pertama-tama memaksudkan komunikasi bahasa-bahasa yang memberi inspirasi bagi semua.

Dialogalitas mengandaikan kecerdasan dialogal, negosiatif. Fungsi kontrol societas dialogal menggarap perilaku keadaban publik secara efektif. Untuk itu diperlukan sebuah kecerdasan baru, kecerdasan dialogal. Halnya terealisasikan dalam apa yang disebut cara merasa, cara berpikir, cara bertindak, cara mempersepsi, dan cara berelasi dalam skema-skema baru. Perbaikan keadaban publik membutuhkan skemaskema terobosan baru yang cerdas dalam berdialog, bernegosiasi.

Dialogalitas menentang prinsip anarkis, monolit, komunalistis (di dalamnya juga sistem hukum yang mempromosikan ke arah sana). Kebijakan yang monolit, anarkis, dan komunalistis melawan hakikat socie- 
tas dialogal. Monolit artinya mengajukan satu persepsi kebijakan yang menguntungkan institusi atau kelompok tertentu sedemikian rupa sehingga melindas pluralitas. Sementara anarkis memaksudkan benihbenih pemicu kekerasan dan kengawuran. Komunalistis menunjuk pada perilaku yang mengedepankan kelompok sendiri dengan menyisihkan siapa pun yang bukan kelompoknya. Halnya bisa mengenai suku, ras, asal-usul, tingkat ekonomi, agama, maupun preferensi aliran politik tertentu. A neka peraturan daerah yang agamis, misalnya, dengan mudah akan terjebak ke arah sana, selain de facto merupakan bentukbentuk manipulatif terhadap Konstitusi. N ota 2004 memberikan indikasiindikasi anarkis yang perlu disimak, termasuk di dalamnya militerisme:

Salah satu sumber kekerasan adalah penyakit sosial yang disebut komunalisme. Masyarakat yang terjangkit penyakit ini memandang orang yang tidak termasuk kelompoknya (agama, suku atau pengelompokan yang lain) sebagai saingan atau bahkah musuhnya. Pola berpikir mereka bukan benar atau salah, melainkan menang atau kalah. Dengan pola berpikir seperti itu, kekerasan amat mudah digunakan untuk merebut apa yang dikehendaki, yaitu kemenangan. Sementara itu kekerasan sering dihubungkan dengan militer dan militerisme... Militerismesecara sadar atau tidak merasuk ke dalam lembaga-lembaga sipil, termasuk lembaga agama, menyulut dan menyebarkan kekerasan dan dengan demikian merusak semuanya. Merebaknya budaya kekerasan dalam masyarakat tidak bisa dipisahkan dari kegagalan aparat keamanan dalam memberikan perlindungan dan rasa aman bagi masyarakat. ${ }^{58}$

Dialogalitas mempromosikan budaya damai. Emblem terpenting dari societas dialogal adalah terciptanya dialog perdamaian, sebuah dialog yang meletakkan prinsi-prinsip perdamaian di atas segalanya. Gereja menggarisbawahi pentingnya perkara ini. Dialog tentang perdamaian tidak boleh disimplifikasi sebagai realitas tidak ada konflik. Perdamaian memaksudkan pertama-tama realitas kondusif yang melukiskan kerjasama, solidaritas, saling membantu dalam kesulitan, saling menanggung beban kehidupan yang tidak ringan. Dialog perdamaian merupakan

58 N ota $2004,6.2$. 
sebutan untuk kreativitas partisipatif dan efektif dari semua orang untuk menggarap tata hidup bersama. Berkaitan dengan hal ini Gereja Katolik Indonesia menegaskan:

Ketika masyarakat dikondisikan untuk mencapai tujuan dengan menghalalkan segal a cara, Gereja perlu mengembangkan dalam dirinya sendiri budaya damai (dialog, kerjasama, musyawarah, saling menghormati). Gereja harus terbuka, efektif dan efisien dalam mengemban perannya sebagai persekutuan yang partisipatif, yang mendorong umat terlibat secara proaktif dalam dial og kemanusiaan demi terwujudnya persaudaraan yang tahan uji..$^{59}$

Dalam societas dialogal diajukan ketulusan dan validitas kesepakatan. Kesepakatan bahasa merupakan elemen penting untuk membangun dialogalitas. Tentang norma-norma, dial og mesti sampai pada kesepakatan yang valid perihal sincerity, bahwa ketidakjujuran merupakan keburukan. Juga, bahwa korupsi merupakan tindakan yang melukai tata kehidupan bersama.

Esensi dialogalitas ada dalam keseharian pengalaman hidup, kesadaran punya "gawe" bersama. Societas dialogal tidak mengandaikan sebuah "panggung pertunjukan" aktivitas dialog seperti yang dijalankan dalam aktivitas formal. Esensi dari makna societas dialogal terletak pada keseharian pengalaman hidup, kesadaran bahwa Indonesia adalah rumah kita sendiri, keluarga kita, tanggung jawab kita, juga "gawe" (karya) kita bersama. Indonesia adalah "rumah tangga" kita. ${ }^{60}$

Tiga N ota tersebut bagaikan meretas jalan-jalan baru, mempromosikan pelibasan segala rintangan dan hambatan, bagi bangsa kita, untuk melangkah membangun tata hidup bersama, bersahabat dan berkolaborasi satu sama lain dengan siapa saja. Tidak ada yang dikecualikan. M enciptakan tata kehidupan baru, societas dialogal.

59 N ota 2004, 18.3.

$60 \mathrm{~N}$ ota $2006,5$. 


\section{PENUTUP}

Gereja Katolik tidak mungkin menutup mata terhadap aneka tekad dan kehendak baik yang dicetuskan oleh umat beragama lain. Dari sebab itu perlulah makin digalakkan kerjasama yang semakin kerap, konkret, dan efektif dengan umat beragama lain dalam dialog.

Di lain pihak, dialog interreligius di Indonesia harus juga dicegah dari sikap-sikap mendangkal sementara umat Kristiani yang menganggap bahwa semua agama sama saja. Pandangan yang menganggap semua agama sama tentu saja merupakan pandangan yang terlalu simplistis. Pandangan yang demikian tidak dikehendaki oleh imperatif dokumendokumen Konsili Vatikan II dan Pascakonsili Vatikan II, sebab sangat mudah tergelincir pada sikap indiferentisme dalam menghayati agamanya. Indiferentisme berarti sikap acuh tak acuh terhadap penghayatan kehidupan agamanya. Indiferentisme melukiskan mendangkalnya iman, sekaligus menawarkan relativisme dalam arti negatif terhadap nilai-nilai agama. la membuang kemantapan pendirian dalam meyakini suatu agama, justru seringkali karena motivasi yang tampaknya baik (memandang semua agama sama baiknya). Bila Gereja mencegah umatnya untuk bersikap tidak peduli (indiferent), itu tidak berarti bahwa Gereja mengajak mereka untuk memandang tinggi agama mereka dan merendahkan agama-agama lain. Sama sekali bukan itu yang dimaksudkan. Anjuran untuk mencegah sikap-sikap tidak peduli (indiferent) dimaksudkan untuk mendorong mereka agar mereka memiliki pandangan dan pendirian yang kokoh dal am beriman; sebab suatu dialog interreligius yang sejati, sangat mengandaikan kemantapan pendirian dan keseriusan dalam menjalankan agamanya. Tanpa kemantapan pendirian, tidak ada dialog.

Dalam konteks situasi yang masih saja rawan dan peka-terutama berkaitan dengan kehidupan beragama-dialog interreligiusterasa menemukan kepentingannya yang mutlak untuk terus diusahakan. Gereja harus tetap menegaskan peranannya sebagai pendukung utama gerakan-gerakan praksis dialog. Gereja Indonesia telah mencetuskan 
dirinya sebagai Gereja Abdi ${ }^{61}$ yang digunakan oleh Tuhan untuk membangun Kerajaan-Nya. Karena Gereja percaya bahwa Kerajaan Allah itu sudah mulai tumbuh di antara kita, maka ia melayani, menyambut baik, mendukung, ikut terlibat memajukan usaha-usaha untuk membangun dialog yang dimaksudkan guna merukunkan semua kaum beriman. Kendati untuk itu Gereja harus menyusuri lorong-lorong gelap yang seringkali menampilkan ketidakpastian dan perjuangan salib berat. Tetapi justru karena itu, Gereja ditantang untuk semakin merealisasikan perannya sebagai tanda dan sarana keselamatan bagi semua manusia dengan terus-bersama kaum beriman lain-berusaha menjalin dialog untuk membangun Kerajaan Allah. Sebuah panggilan yang mendesak untuk dilaksanakan, biar pun tidak ringan.

\section{DAFTAR RUJUKAN}

Armada Riyanto. Dialog Interreligius: H istorisitas, Tesis, Pergumulan, W ajah. Yogyakarta: Kanisius, 2010.

Banawiratma, J.B. "Teologi Fungsional - Teologi Kontekstual." Dalam Eka Darma Putera (Ed.), Konteks Berteologi Di Indonesia. Jakarta: BPK Gunung Mulia, 1989, hlm. 47-64. . "Wujud Baru Hidup Menggereja: Dialogal dan Transformatif." Orientasi Baru 5 (1991): 9-13.

Coward, Harold. Pluralism: Challenge to W orld Religions. N ew York: Orbis Books, 1985.

Dokpen MAWI. U mat Katolik Indonesia Dalam M asyarakat Pancasila: Hubungan Gereja dan N egara. Pedoman M AWI bagi U mat Katolik. Jakarta: Dokumentasi dan Penerangan MAWI, 1985

Hardawiryana, Robertus. “Ensiklik Redemptoris Missio-Dokumen Dialog dan Proklamasi." Spektrum 20 (1992): 9-16.

. "Peranan Gereja dalam Masyarakat Plurireligius di Asia." O rientasi, 5 (1991): 14-67.

Jacobs, Tom. Gereja M enurut V atikan II. Yogyakarta: Kanisius, 1987.

61 Dokpen MAWI, U mat Katolik Indonesia D alam M asyarakat Pancasila: H ubungan Gereja dan N egara. P edoman M A W I bagi U mat K atolik (Jakarta: Dokumentasi dan Penerangan MAWI, 1985), no. 9, hlm. 5. 
. Konstitusi Dogmatis "Lumen Gentium" mengenai Gereja: Terje mahan, Introduksi, dan Komentar. Jilid I. Yogyakarta: Kanisius, 1974. . “Misi dan Kristologi." O rientasi Baru 5 (1991): 68-91.

Jadot, Jean L. "The Growth in Roman Catholic Commitment to Interreligious Dialogue Since Vatican II." Journal of Ecumenical Studies 20 (Summer 1983): 365-378.

John Paulus II. "Believer United in Building Peace." Catholic International 3:3, 1-14 (February 1992): 102-105.

. "Called to Unity in Dialogue of Truth and Love." L'O sservatore Romano 18 (1980): 1-2.

Küng, Hans. "Introduction: The Debate on the World Religions." Concilium 183 (1/ 1986): xi-xv. . On Being A Christian. New York: Doubleday, 1976. . "Toward A New Concensus in Catholic (and Ecumenical) Theology." Journal of Ecumenical Studies 17 (Winter, 1980): 1-17.

Küng, Hans and David Tracy (Eds.). Paradigm Change in Theology: A Symposium For The Future. Edinburgh: T\&T. Clark Ltd., 1989.

Mardiatmaja, B. S. "Hubungan A ntarumat Aneka Beragama di Negara Pancasila." Hak Kerukunan 12 (Maret-Juli 1991): 69-71.

Pareira, Berthold A. Dialog Kristen-Islam. (Makalah Hari Studi STFT Widya Sasana, Malang, Oktober 1992).

. "Evangelisasi dan Dialog dengan Agama-Agama Bukan Kristen." Forum 18 (1990): 4-11.

Pieris, Aloysius. The Church, the Kingdom and O ther Religions. Colombo: Study Center, 1968.

. Love M eets W isdom: A Christian Experience of Buddhism. Quezon City: Claretian Publications, 1989.

Rahner, Karl. "A nonymous and Explicit Faith." In Karl Rahner, Theological Investigation. V olume XVI. New York: Seabury Press, 1979, pp. 52-59.

. "Christianity and The Non-Christian Religions." In Karl Rahner, Theological Investigation. V olume V. London: Darton, Longman \& Todd, 1966, pp. 115-134.

. "The One Christ and The Universality of Salvation." In Karl Rahner, Theological Investigation. Volume XVI. New York: Seabury Press, 1979, pp. 199-224. 
. "One Mediator and Mediations." In Karl Rahner, Theological Investigation. V olume IX. N ew York: Herder and Herder, 1972, pp. 169-184.

. "Observations on the Problem of the 'A nonymous Christian'." In Karl Rahner, Theological Investigation. V olume XIV. London: Darton, Longman \& Todd, 1976, pp. 280-294.

Suhardi, Alfons. “Pekabaran Injil dalam Konteks Pluralitas Keagamaan di Indonesia." Hak Kerukunan 12 (Maret-Juli 1991): 69-71.

Swidler, Leonard (Ed.). Toward A U niversal Theology Of Religion. New York: Orbis Books, 1987.

Tule, Philipus. Bermisi Dalam Semangat Dialog dengan Islam. (Makalah yang disampaikan di depan Senat Mahasiswa, STFT Widya Sasana, Malang, 4 Desember 1991). 